\title{
ARTI PENTING DELIMITASI PERAIRAN PEDALAMAN SETIAP PULAU DI INDONESIA
}

\author{
Maria Maya Lestari \\ Fakultas Hukum Universitas Riau \\ Jl. Pattimura, No. 9, Cinta Raja, Riau
}

\begin{abstract}
Maritime zones of the sovereignty of the Indonesian archipelago can be divided into inland waters, archipelagic waters and territorial sea. But only in the inland waters of Indonesia have absolute sovereignty without any other state right. In order to guarantee and maintain the sovereignty of the country in the inland water zone from overlapping interests and rights of other countries in the zone of Indonesian maritime sovereignty, Indonesia should immediately establish the limits of delimitation of the inland waters and establish legislation to prevent violations of the sovereignty of Indonesia's inland waters territory by the state other. Delimitation of each islands is considered very important in order to maintain the security and defense of the country. The government must immediately establish inland water areas and ports considered strategic and vital to the defense and security of the country. Areas that are considered important this can be closing and banning to enter and / or stopover. So our marine law is firm and we can become a sovereign country in the sea region.
\end{abstract}

\section{Keywords: Delimitation, Maritime Zone, Inland Water}

\begin{abstract}
Abstrak
Zona maritim kedaulatan laut negara kepulauan Indonesia dapat dibagi atas perairan pedalaman (Internal Water), perairan kepulauan (archipelagic water) dan laut territorial (territorial sea). Namun hanya di perairan pedalaman saja Indonesia memiliki kedaulatan absolut tanpa adanya hak negara lain. Guna menjamin dan menjaga kedaulatan negara di zona perairan pedalaman dari tumpang tindih kepentingan dan hak negara lain di zona kedaulatan maritim Indonesia, maka Indonesia mesti segera menetapkan batas delimitasi perairan pedalaman dan membentuk peraturan perundang-undangan untuk mencegah pelanggaran terhadap kedaulatan wilayah perairan pedalaman Indonesia oleh negara lain. Penetapan delimitasi setiap kepulauan dianggap sangat penting dalam rangka menjaga keamanan dan pertahanan negara. Pemerintah mesti segera menetapkan kawasan-kawasan perairan pedalaman dan pelabuhan-pelabuhan yang dianggap strategis dan vital bagi pertahanan dan keamanan negara. Wilayah yang dianggap penting ini dapat dilakukan penutupan dan pelarangan untuk memasuki dan/ataupun singgah. Sehingga hukum kelautan kita tegas dan kita bisa menjadi negara yang berdaulat di wilayah laut.
\end{abstract}

Keywords : Delimitasi, Zona Maritim, Perairan Pedalaman 


\section{A. PENDAHULUAN}

Diterimanya konsep negara kepulauan pada Konferensi Hukum Laut 1982 (the United Nations Conference Law of the Sea/ UNCLOS 1982) merupakan bukti keberhasilan diplomatic pemerintah Indonesia dalam memperjuangkan konsep negara kepualauan di dunia inetrnasional. Sebagai suatu consensus UNCLOS 1982 menghasilkan Law of the Sea Convention 1982 (LOSC 1982), dimana BAB IV LOSC merupakan pengakuan Internasional terhadap kedaulatan negara kepulauan yang juga telah disesuaikan dengan kepentingan dan hak negara lain yang telah lebih dulu ada sebelum LOSC 1982 ditetapkan. $^{1}$

Keuntungan utama negara dengan bentuk negara kepulauan adalah dalam penarikan garis pangkal, yaitu dapat menarik garis pangkal lurus kepulauan yang menghubungkan titiktitik terluar pulau-pulau dan karang kering terluar kepulauan itu, dengan ketentuan bahwa didalam garis pangkal demikian termasuk pulau-pulau utama dan suatu daerah dimana perbandingan antara daerah perairan dan daerah daratan, termasuk atol, adalah antara satu berbanding satu dan sembilan berbanding satu. ${ }^{2}$

Penetapan garis pangkal kepulauan sangat penting bagi sebagai batu pijakan penarikan zona maritime. Dimana zona maritime tersebut terdiri dari internal water (perairan pedalaman), territorial sea (laut territorial), contiguous zone (zona tambahan), exclusive economic zone (zona ekonomi eksklusif), continental shelf (landas kontinen), and archipelagic waters (perairan kepulauan) yang hanya dimiliki oleh negara kepulauan. ${ }^{3}$

Namun bila berbicara mengenai zona maritime yang merupakan ranah "kedaulatan" negara kepualauan maka hanya terdiri atas 3 zona maritime yaitu:

1. Internal water (perairan pedalaman), yaitu perairan pada sisi darat garis pangkal laut teritorial merupakan bagian perairan pedalaman Negara tersebut. ${ }^{4}$

2. Territorial Sea (laut territorial), yaitu lebar laut teritorialnya sampai suatu batas yang tidak melebihi 12 mil laut, diukur dari garis pangkal yang ditentukan sesuai dengan Konvensi ini. ${ }^{5}$

3. Archipelagic waters (perairan kepulauan), yaitu perairan yang ditutup oleh garis pangkal kepulauan, yang ditarik sesuai dengan ketentuan pasal 47, disebut sebagai perairan

kepulauan, tanpa memperhatikan kedalaman atau jaraknya dari pantai. ${ }^{6}$

Meskipun ketiga zona maritime diatas masuk kedalam ranah kedaulatan negara kepulauan, namun konsep kedaulatan pada tiga zona tersebut berbeda. Untuk zona internal water kedaulatan bersifat absolut sedangkan zona territorial sea dan archipelagic water

\footnotetext{
John R. Brock, Archipelago Concept of Limits of Territorial Seas, International Law Studies, (Vol. 61, tanpa tahun), hal. 334-335. 
bersifat relative. ${ }^{7}$ Dikatakan absolut ${ }^{8}$ bahwa tidak terdapat hak negara lain di zona inland water dan hukum yang berlaku tunduk dibawah yurisdiksi hukum nasional ${ }^{9}$ berbeda dengan zona territorial sea dan archipelagic water terdapat hak negara lain, sehingga pelaksanaan hak negara lain di kedua zona maritime tersebut tunduk kepada hukum internasional dan bila ada penetapan hukum nasional maka pemberlakuannya mesti sesuai dengan hukum internasional. Seperti hak peletakan dan perbaikan kabel bawah laut, hak perikanan tradisional, hak melintas dan hak lainnya yang diatur secara sah oleh LOSC. ${ }^{10}$ Untuk itulah, pembahasan dalam paper ini akan membahas mengenai status hukum, hak akses kepelabuhan, dan yurisdiksi internal water guna untuk menjaga kedaulatan wilayah dan hukum Indonesia.

\section{B. PEMBAHASAN}

Delimitasi berasal dari bahasa Inggris 'Delimit' / batas. Sedangkan The delimitation of maritime boundaries / penetapan batas maritim merupakan fenomena baru yang merupakan elemen penting praktek kenegaraan menurut hukum laut internasional modern yaitu LOSC 1982. Selain dapat menyebabkan tumpang tindih klaim batas maritime, hal ini juga termasuk kedalam kategori proses politik yang sensistif. Dimana efek dari penetapan batas maritime ini tidak hanya digunakan untuk menentukan zona maritime (yang berada dibawah yurisdiksi suatu negara) namun juga menentukan hak dan kepentingan negara pantai terhadap perikanan dan sumber daya alam, mineral dan hydrocarbon, navigasi dan lainnya. ${ }^{11}$

Penentuan delimitasi sangat tergantung kepada baseline / garis pangkal sangat penting bagi setiap negara pantai apalagi negara kepulauan seperti Indonesia. Pengaturan secara umum mengenai garis pangkal dapat ditemukan dalam $:^{12}$

1. Pasal 3 - 11 dan pasal 13 Convention on the Territorial Sea and Contiguous Zone 1958 (TSC);

2. Pasal 4-14, pasal 16 dan pasal 47 LOSC 1982

7 Kresno Buntoro, Alur Laut Kepulauan Indonesia (ALKI) Prospek dan Kendala, Sekolah Staf dan Komando TNI AL (Seskoal), 2012 hal 31.

8 Ada beberapa penulis menyebutkan istilah "kedaulatan absolut" oleh Kresno Buntoro, "full territorial sovereignty" oleh R.R. Churchill dan A.V. Lowe, "complete authority” oleh Lung Chu Chen, dan "exercises full sovereignty" oleh MOM Ravin, untuk keseragaman penulisan akan digunakan istilah kedaulatan absolut mengingat ranah pembahasan merupakan ranah kedaulatan wilayah laut dan secara umum dalam hukum tatanegara padanan kata kedaulatan lebih lazim menggunakan istilah kedaulatan absolut dan lawannya kedaulatan relative.

9 Ibid, MOM Ravin, lihat juga R.R. Churchill dan A.V. Lowe, The Law of the Sea, (Manchester : Manchester University Press, 1988), hal. 51., lihat juga

10 Ibid, LOSC pasal 17, 51, 52, 53 dan lihat juga Churchill, hal. 103-104.

11 Division for Ocean Affairs and the Law of the Sea Office of Legal Affairs, Handbook on the Delimitation of Maritime Boundaries (New York : United Nations, 2001), hal. 1, available on http://www.keepeek.com/Digital-Asset-Management/oecd/international-law-and-justice/handbook-on-thedelimitation-of-maritime-boundaries_cc72cd88-en\#.WDDU4xQQjZs, access at 15/11/2016, pukul 02.15 WIB.

12 Tim Hillier, Sourcebook on Public International Law, (London : Cavendish Publishing Limited, 1998), hal. 371. 
Aturan diatas merupakan representasi dari hukum kebiasaan internasional. Sedangakn titik awal untuk menggambarkan garis pangkal garis pangkal adalah dengan menentukan garis air rendah (low-water line) disepanjang pantai. ${ }^{13}$

Secara khusus untuk negara kepulauan seperti Indonesia akan menggunakan garis pangkal kepulauan sebagaimana diatur dalam pasal 47 (1) LOSC menyatakan :

"An archipelagic State may draw straight archipelagic baselines joining the outermost points of the outermost islands and drying reefs of the archipelago provided that within such baselines are included the main islands and an area in which the ratio of the area of the water to the area of the land, including atolls, is between 1 to 1 and 9 to $1 . "$

Bahwa negara kepulauan dapat menarik garis pangkal kepulauan (archipelagic baseline). Konsep garis pangkal kepulauan disini adalah untuk sebagai dasar penentukan demitasi maritime Indonesia terutama kearah luar menentukan untuk batas negara, menutup perarairan kepulauan, penentun zona hak berdaulat dan zona ekslusif serta zona laut lepas. ${ }^{14}$

Dengan kata lain garis pangkal kepualauan merupakan garis penutup yang akan mempermudah penarikan garis territorial 12 mil kearah luar garis pangkal serta penarikan garis lainnya, sedangkan sisi dalam garis pangkal kepulauan akan disebut sebagai perairan kepulauan ${ }^{15}$. Didalam perairan kepulauan itu sendiri, setiap negara kepulauan dapat pula menarik garis-garis penutup untuk keperluan penetapan batas perariran pedalaman, yang mesti sesuai dengan pasal 9 LOSC tentang mulut sungai, pasal 10 tentang teluk dan pasal 11 tentang pelabuhan. ${ }^{16}$

Dikatakan sebagai Internal / national / interior waters (perairan pedalaman) merupakan seluruh perairan yang berada disisi daratan atau sisi dalam suatu garis pangkal yang mana laut territorial ${ }^{17}$ dan zona maritime lainnya ditetapkan. ${ }^{18}$ Internal water ini meliputi mulut sungai, teluk, pelabuhan, tempat berlabuh ditengah laut, dan semua perariran yang ditutup oleh garis pangkal lurus ${ }^{19}$, teluk bersejarah, ceruk (inlet), atoll dan gugusan terumbu karang. $^{20}$

\section{Gambar : Garis Pangkal Kepulauan dan Internal Waters}

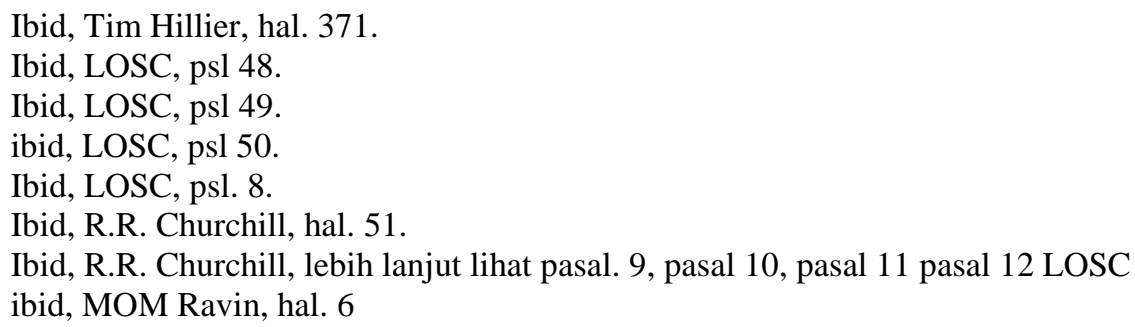




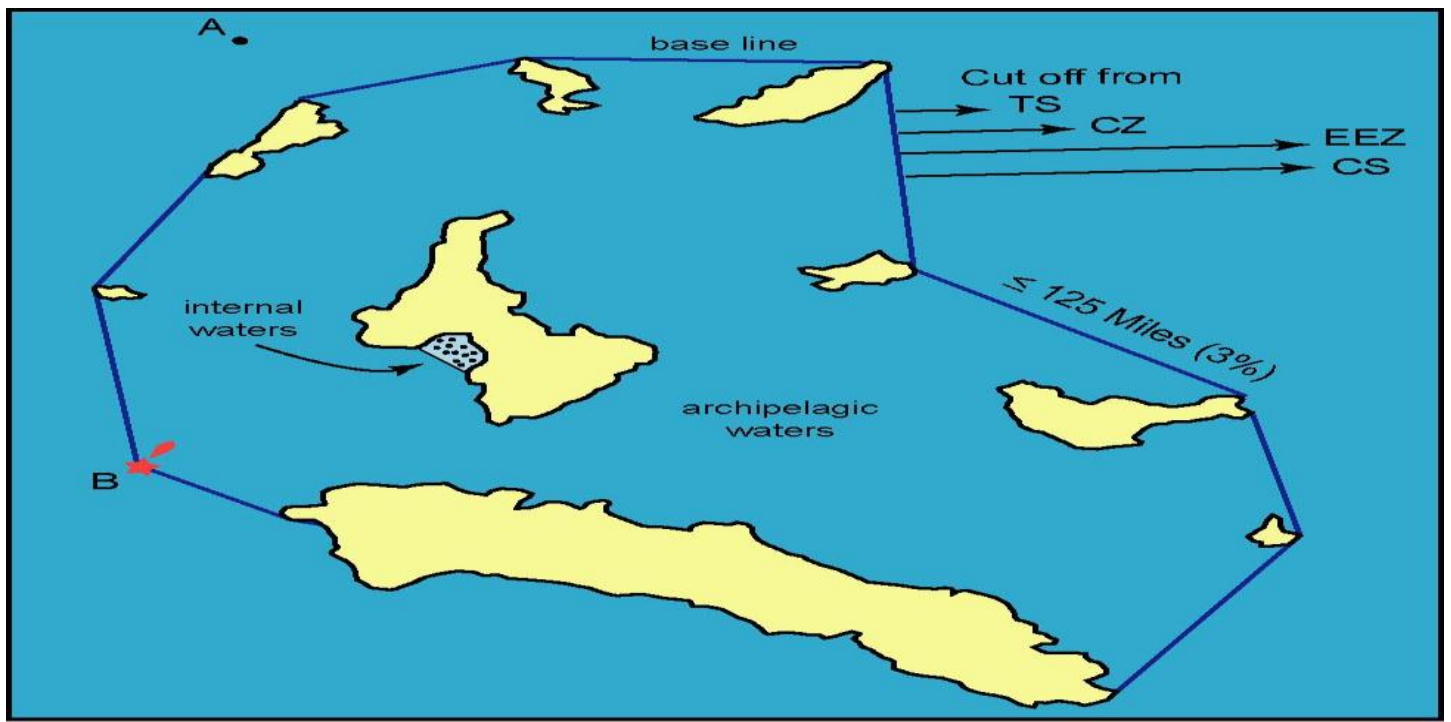

Sumber: A Manual on Technical Aspects of the United Nations Convention on Law of the Sea 1982 (Talos), Bab 4, hal 8

\section{Status Hukum Perairan Pedalaman}

Perairan pedalaman yang berada disisi dalam garis pangkal kearah dataran merupakan sebuah bagian yang integral dengan dari territorial negara pantai. Tidak ada satupun ketentuan hukum internasional berlaku di internal water dan negara pantai dapat menikmati secara penuh kedaulatan ${ }^{21}$ dan hukum nasionalnya di perairan pedalaman.

Hukum internasional memberikan kewenangan kepada negara untuk membuat peraturan hukum, mengatur penggunaan perairan pedalamannya dan memutuskan siapa saja yang boleh memasuki, yang boleh keluar serta hal-hal yang boleh dilakukan saat memasuki perairan pedalaman. ${ }^{22}$ Kekuasaan penuh negara di perairan pedalamannya, disebabkan kondisi geografi perairan pedalaman terletak berdampingan dengan territorial daratan suatu negara. ${ }^{23}$

Perairan pedalaman memiliki persamaan rejim dengan zona perairan kepaulauan dan laut territorial namun juga berbeda memiliki perbedaan dengan kedua rejim lainnya, sebagai berikut :

Tabel 1.

\section{Perbedaan Rejim Perairan Pedalaman, Perairan Kepulauan dan Laut Teritorial}

\begin{tabular}{|c|c|c|c|}
\hline Keterangan & $\begin{array}{c}\text { Perairan } \\
\text { Pedalaman }\end{array}$ & Perairan Kepulauan & Laut Teritorial \\
\hline Rejim Kedaulatan & Kedaulatan absolut & Kedaulatan relatif & Kedaulatan relatif \\
\hline $\begin{array}{l}\text { Terdapat Hak } \\
\text { Lintas kapal asing }\end{array}$ & Tidak & $\begin{array}{l}\text { - Hak Lintas Alur Laut } \\
\text { Kepulauan } \\
\text { - Lintas damai/ innocent }\end{array}$ & Innocent passage \\
\hline
\end{tabular}

21 Ibid, R.R. Churchill and A.V. Lowe, hal. 51, lihat juga dalam Tim Hillie, hal. 377

22 Lung Chu Chen, An Introduction to Contemporary International Law a Policy Oriented Perspective $2^{\text {nd }}$ Edition, (New Haven : Yale University Press, 2000), hal. 133.

23 ibid, Lung Chu Chen, hal. 133, lihat juga John R. Brock, hal. 332. 


\begin{tabular}{|c|c|c|c|}
\hline & & passage & \\
\hline $\begin{array}{l}\text { Terdapat hak } \\
\text { negara lainnya }\end{array}$ & Tidak & $\begin{array}{l}\text { Ya, seperti pipa, kabel } \\
\text { dasar laut, dll }\end{array}$ & $\begin{array}{l}\text { Ya, terdapat hak } \\
\text { perikanan } \\
\text { tradisional negara } \\
\text { lain. }\end{array}$ \\
\hline $\begin{array}{l}\text { Terdapat Hak } \\
\text { Accest Pelabuhan }\end{array}$ & Ya & $\begin{array}{lr}\text { - ALKI tidak } & \\
\text { - Lintas damai : } & \\
\text { 1. ya, bila } & \text { kapal } \\
\text { bertujuan } & \text { untuk } \\
\text { singgah } & \text { dan } \\
\text { memasuki } & \text { perairan } \\
\text { pedalaman } & \\
\text { 2. tidak bila } & \text { kapal } \\
\text { hanya } & \text { melintas/ } \\
\text { passing. } & \end{array}$ & $\begin{array}{l}\text { - Lintas damai : } \\
\text { 1. ya, bila kapal } \\
\text { bertujuan } \\
\text { untuk singgah } \\
\text { dan memasuki } \\
\text { perairan } \\
\text { pedalaman } \\
\text { 2. tidak bila } \\
\text { kapal hanya } \\
\text { melintas/ } \\
\text { passing. }\end{array}$ \\
\hline $\begin{array}{l}\text { Laut dan Pelayaran } \\
\text { dapat ditutup/ } \\
\text { ditunda oleh negara } \\
\text { pantai }\end{array}$ & $\begin{array}{l}\text { Ya, bila negara } \\
\text { pantai menganggap } \\
\text { perlu dan bersifat } \\
\text { vital }\end{array}$ & tidak & $\begin{array}{ll}\text { Dapat, } & \text { dengan } \\
\text { syarat } & \\
\text { pemberitahuan } \\
\text { terlebih dahulu } \\
\text { kepada } & \text { negara } \\
\text { pengguna } & \\
\end{array}$ \\
\hline Yurisdiksi & $\begin{array}{l}\text { Tunduk kepada } \\
\text { hukum nasional }\end{array}$ & $\begin{array}{lr}\text { Tunduk kepada } & \text { rejim } \\
\text { hukum } & \\
\text { internasional } & \end{array}$ & $\begin{array}{l}\text { Tunduk kepada } \\
\text { rejim hukum laut } \\
\text { internasional }\end{array}$ \\
\hline
\end{tabular}

\section{Hak Akses Kepelabuhan}

Meskipun tidak ada hak lintas damai (innocent passage) dari kapal asing diwilayah perairan pedalaman, serta kapal asing tidak dapat menikmati hak akses secara umum ( $a$ general right) ke pelabuhan suatu negara, hukum kebiasaan internasional mengatur suatu rejim khusus yang dikenal dengan hak akses ke pelabuhan (right of access to a state's ports). ${ }^{24}$

Secara tegas LOSC tidak mengatur mengenai apakah kapal asing memiliki hak untuk akses kepelabuhan, namun terdapat dua perjanjian hukum (treaty law) dan kasus hukum yang mendukung prinsip umum mengenai batasan negara pantai untuk melarang kapal asing akses ke pelabuhannya. Perjanjian tersebut yaitu Convensi 1923 (the 1923 Convention) dan Statuta on the International Regime of Maritime Ports, telah memberikan pengakuan umum mengenai perlakuan yang sama terhadap semua anggota dalam kaitannya dnegan hak akses kepelabuhan. Prinsip ini diakui dalam kasus Saudi Arbia v Aramco tahun 1958, dimana arbiter menyatakan bahwa : ${ }^{25}$

24 Ibid, Lung Chu Chen, hal. 133

25 Donald R. Rothwell and Tim Stephens, The International Law of the Sea, p. 125-126 
"According to a great principle of public international law, the ports of every state must be open to foreignt merchant vessels and can only be closed when the vital intersts of the state so require."

Demikian juga halnya dengan kasus 1986 Nikaragua, ICJ juga menyebutkan hak-hak tertentu yang berkaitan dengan kebebasan komunikasi dan perdagangan maritime, dimana ICJ memutuskan untuk memberikan kebebasan kepada kapal asing untuk menikmati "hak akses" ke pelabuhan. $^{26}$

Berdasarkan kasus Saudi - Aramco diatas, walaupun terdapat hak akses kapal asing ke pelabuhan, hukum internasional juga menjamin kedaulatan dan hak negara pelabuhan untuk menutup akses kepelabuhan wilayahnya, apakah untuk kepentingan yang vital, keamanan,ataupun untuk alasan-alasan tertentu lainnya. ${ }^{27}$

\section{Yurisdiksi Perairan Pedalaman}

Ketika kapal asing memasuki pelabuhan dan perairan pedalaman suatu negara pantai maka dapat saja terjadi konflik yurisdiksi antara kapal negara bendera dengan negara pelabuhan / perairan pedalaman. Masing-masing akan berusaha untuk mengutamakan hukum dan penegakan hukum mereka terhadap kejadian atau peristiwa yang terjadi. Berdasarkan kasus The Schooner Exchange v. Mc Faddon (1812), dalam kasus ini bahwa bila kapal asing memasuki pelabuhan negara pantai akan tetap tunduk terhadap kedaulatan dan yurisdiksi negara pelabuhan. ${ }^{28}$

Setiap kapal yang memasuki pelabuhan dan perairan pedalaman, maka itu berarti kapal tersebut telah tunduk kepada kedaulatan negara pantai. ${ }^{29}$ Hukum yang berlaku di perairan pedalaman memiliki karakter rejim hukum yang sama dengan daratan (dalam artian berlaku yurisdiksi hukum nasional negara kepulauan) dan setiap kapal yang memasuki perairan pedalaman maka berlakulah hukum nasional negara pantai tersebut terhadapnya. ${ }^{30}$ Subjek penegakan hukum di perairan pedalaman ini atau pelabuhan ini dapat berupa tindakan criminal, keperdataan dan aturan lainnya yang ditetapkan oleh negara pelabuhan. Untuk pelanggaran criminal kecil (minor criminal) yang berkaitan dengan masalah kedisiplinan di kapal, negara pantai dapat untuk tidak menerapkan hukum pidana mereka. Namun bila tindak pidana di kapal mempengaruhi kepentingan negara pantai maka akan berlakulah hukum mereka. ${ }^{31}$

Hal-hal yang berkaitan dengan keperdataan dan administrasi tergantung kepada bentuk pelanggaran yang dilakukan. Bila kasus tersebut berkaitan dengan pelaku dikapal permasalahan "internal economy" dari kapal dan orang diatasnya maka akan tetap berlaku hukum negara negara bendera atau hukum kapten kapal atau local consul yang ada didaerah

ibid, Donald R. Rothwell, hal. 126

Louis B. Sohn, Cases and Materials on the Law of the Sea $2^{\text {nd }}$ edition, (Leiden: Brill Nijhoff, 2014), hal.351

Ibid, Louis B. Sohn, hal.362-363

Churchill, ibid, hal. 54

ibid, hal 50-54

31 ibid, Donald R. Rothwell and Tim Stephen, hal. 127 
tersebut. dan bilamana negara pantai dimintakan bantuan, maka negara pantai hanya sebatas memberikan bantuan bukan berarti melakukan penegakan hukum, penegakan hukum tetap dikembalikan kepada negara bendera kapal. ${ }^{32}$

Salah satu keterbatasan tertentu adalah pemberlakuan ketentuan terhadap kapal asing yang melintas dari laut teritorial menuju ke perairan internal seperti pelabuhan. Kesulitannya adalah penerapan undang-undang yang relevan bagi negara pesisir itu sendiri seperti hal-hal yang berkaitan dengan masalah desain, konstruksi, awak dan peralatan kapal asing. Akan lebih baik jika negara pesisir telah mengadopsi standar tersebut, yang akan mencakup IMO instructrument seperti SOLAS. Hal terpenting dari instrument ini adalah pencegahan dan regulasi di kedua perairan yaitu di laut teritorial dan perairan, yang mengarah untuk membuat ketentuan lebih ketat diterapkan untuk kapal di perairan pedalaman. Hal ini dimaksud dalam LOSC pasal 211(3) yang mengharuskan negara-negara yang menetapkan persyaratan tertentu untuk pencegahan, pengurangan dan pengendalian pencemaran lingkungan laut sebagai syarat untuk masuknya kapal asing ke dalam pelabuhan atau perairan pedalaman serta memberikan pemberitahuan yang tepat sesuai dengan persyaratan dan ketentuan IMO. ${ }^{33}$

\section{Kondisi Indonesia terkini}

Saat ini Indonesia telah memiliki garis pangkal kepulauan, delimitasi territorial, bahkan delimitasi ZEE. Namun sangat disayangkan Indonesia belum menetapkan delimitasi perairan pedalaman. Padahal delimitasi perairan pedalaman sangat penting untuk menutup wilayah pulau-pulau dari pelanggaran penggunaan hak negara lain yang berada di zona perariran kepulauan dan laut territorial.

Pentingnya penutupan perairan pedalaman juga bertujuan untuk mencegah pelanggaran kedaulatan dari kapal-kapal asing yang menggunakan hak lintas damai saat berlayar dari Timur - Barat Indonesia. Mengingat sampai saat ini Indonesia belum menetapkan ALKI Timur dan Barat.

Beberapa wilayah pelabuhan yang padat akan kapal yang bersandar mesti segera ditetapkan pengaturan hukumnya sesuai dengan standar IMO, SOLAS dan peraturan lainnya, guna mencegah terjadinya pencemaran dan perusakan lingkungan akibat tindakan kapal yang berlabuh di wilayah perariran pedalaman Indonesia.

\section{KESIMPULAN}

Bahwa Indonesia dengan 17.500 pulau harus segera menetapkan arti penting delimitasi perairan pedalaman. Zona maritim Indonesia terdiri atas perairan kepulauan, laut kepulauan dan laut territorial, dimana hanya di perairan kepualuan saja tidak terdapat hak negara lain, sedangkan di zona perairan lainnya kedaulatan Indonesia dibarengi dengan hak negara lain. Pentingnya delimitasi perairan kepulauan bertujuan untuk mencegah pelanggaran hak lintas kapal asing dan hak lainnya seperti peletakan kabel bawah laut, pipa dll.

32 Ibid, R.R. Churchill, hal. 54-55

33 ibid. 
Penetapan delimitasi setiap kepulauan penting dalam rangka menjaga keamanan dan pertahanan negara. Pemerintah mesti segera menetapkan kawasan-kawasan perairan pedalaman dan pelabuhan-pelabuhan yang dianggap strategis dan vital bagi pertahanan dan keamanan negara. Wilayah yang dianggap penting ini dapat dilakukan penutupan dan pelarangan untuk memasuki dan/ataupun singgah.

Hukum dan penegakan hukum di lapangan mesti memantau dan melakukan penegakan hukum yang tegas terhadap pelaku pelanggaran yang dianggap membahayakan kepentingan Indonesia. Seperti penetapan peraturan pencegahan pencemaran di sepanjang pelabuhan dan perairan pedalaman dari setiap kegiatan kapal saat berlabuh.

\section{DAFTAR PUSTAKA}

John R. Brock, "Archipelago Concept of Limits of Territorial Seas", International Law Studies, (Vol. 61, tanpa tahun)

MOM Ravin, Law of the Sea Maritme Boundaries and Dispute Settlement Mechanisms, United Nations - The Nippon Foundation Fellow, Germany, March-Desember, 2005

United Nation Convention on Law of the Sea (UNCLOS) Tahun 1982

Kresno Buntoro, Alur Laut Kepulauan Indonesia (ALKI) Prospek dan Kendala, Sekolah Staf dan Komando TNI AL (Seskoal), 2012.

Churchill, R.R. dan Lowe, A.V., The Law of the Sea, Manchester University Press, Manchester, 1988

Division for Ocean Affairs and the Law of the Sea Office of Legal Affairs, Handbook on the Delimitation of Maritime Boundaries, United Nations, New York, 2001

Lung Chu Chen, An Introduction to Contemporary International Law a Policy Oriented Perspective $2^{\text {nd }}$ Edition, Yale University Press, New Haven, 2000

Donald R. Rothwell and Tim Stephens, The International Law of the Sea

Louis B. Sohn, Cases and Materials on the Law of the Sea $2^{\text {nd }}$ edition, Brill Nijhoff, Leiden, 2014 